\begin{tabular}{|l|l|}
\hline Asynchronous modernization of the Mexican press. A center-periphery comparison & Titulo \\
\hline Echeverría Victoria, Martín - Autor/a; González Macías, Rubén - Autor/a; & Autor(es) \\
\hline $\begin{array}{l}\text { En: Global Media Journal México vol. 14 no. 27 (noviembre 2017-abril 2018). } \\
\text { Monterrey : Instituto Tecnológico y de Estudios Superiores de Monterrey, 2018. }\end{array}$ & En: \\
\hline & Lugar \\
\hline Instituto Tecnológico y de Estudios Superiores de Monterrey & Editorial/Editor \\
\hline 2018 & Fecha \\
\hline Modernización; Elecciones; Prensa; México; & Colección \\
\hline Artículo & Temas \\
\hline "http://biblioteca.clacso.edu.ar/Mexico/icgde-buap/20180215120524/Asynchronous.pdf" & Tipo de documento \\
\hline $\begin{array}{l}\text { Reconocimiento-No Comercial-Sin Derivadas CC BY-NC-ND } \\
\text { http://creativecommons.org/licenses/by-nc-nd/2.0/deed.es }\end{array}$ & URL \\
\hline
\end{tabular}

Segui buscando en la Red de Bibliotecas Virtuales de CLACSO http://biblioteca.clacso.edu.ar

Consejo Latinoamericano de Ciencias Sociales (CLACSO)

Conselho Latino-americano de Ciências Sociais (CLACSO)

Latin American Council of Social Sciences (CLACSO)

www.clacso.edu.ar

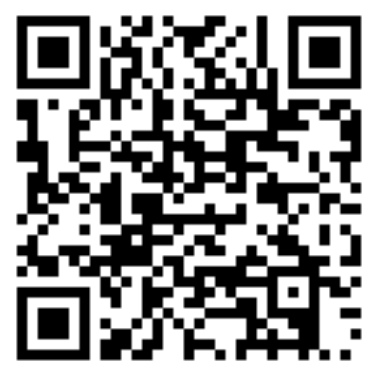




\title{
Asynchronous modernization of the Mexican press. A center-periphery comparison
}

Reporte de Investigación

\author{
Rubén González Macias \\ Martín Echeverría
}

Benemérita Universidad Autónoma de Puebla

Autor para correspondencia: Martín Echeverría, email: echevemartin@yahoo.com.mx 


\title{
Asynchronous modernization of the Mexican press. A center-periphery comparison
}

\section{Authors:}

Rubén González Macías

Martín Echeverría

\begin{abstract}
:
After seventy years of an almost complete hegemony, in 2000 the Institutional Revolutionary Party lost the presidency of the Republic to the oppositional National Action Party candidate, Vicente Fox Quesada. That moment was considered the hallmark of the political transition that started in certain regions two decades ago. According to a group of American scholars, the transformation of the political system involved the modernisation of the media system as well, as the Mexican press as a whole was moving towards its professionalization. Nonetheless, diverse case studies focused on specific regions have found empirical evidence that prove otherwise. That is, the findings consistently prove that local and regional journalism is still determined by the customs of the authoritarian model. Based upon a content analysis of the coverage of the 2015 congressional elections in both national and state newspapers, the main argument of this article is that Mexican journalism oscillates between modernisation and stagnation. In other words, whilst the so-called national media - located in Mexico City - showed a more professional performance than those located in other regions (regarding - for instance - the use of diverse sources of information, and the implementation of different journalistic genres, other than the standard news story); both groups shared a similar political bias and a limited coverage of those elections. Therefore, the main conclusion is that instead of a general transformation or stagnation, Mexican press develops an asynchronous modernisation process in which there are simultaneously liberal and authoritarian features. However, the former are more frequent in national news outlets than in their regional counterparts, which tend to be inclined to the latter.
\end{abstract}

Keywords: Mexican journalism, modernisation, political bias, congressional elections

Recibido: 05/07/2017

Aceptado: 27/11/2017

Global Media Journal México 14(27). Noviembre 2017 - abril 2018. Pp. 149-165. 


\section{Introduction}

A successful transition to democracy entails, amongst other consequences, both a modern media system and journalistic culture, inclined to the values of liberal journalism: objectivity, plurality, independence, balance, etc. Above all, it involves a performance based exclusively on autonomous journalistic criteria, rather than operating as vehicle for external groups to seek public influence. The latter was the case of the Mexican news media almost two decades ago: controlled by mechanisms of self-censorship and external coercion, it behaved as the propaganda branch of the hegemonic regime of the Institutional Revolutionary Party (PRI). Nonetheless, as that status quo got weaker and eventually dismantled, the press and news media gained more autonomy, as some literature demonstrated empirically (Lawson, 2002; Hughes, 2006).

Nevertheless, these conclusions exhibit a biased and incomplete diagnose based on a partial assessment: by taking into account the media from Mexico City, often more economically and politically mature, this literature inferred that the entire national media system had changed. This assertion considered the press published in the capital of the nation as a necessary, but also sufficient condition to generalise their conclusions to the whole country. On the contrary, local press has shown a strong capacity to resist to journalistic modernization since it replicates many of the practices of the authoritarian era: officialdom, clientelism, and open party bias are traits observed by an increasing volume of empirical work (see Orozco, 2010; De León, 2011; González, 2013; Reyna, 2014), that evidence a clear modernization asynchrony between national or central scenario and subnational or local one.

This article presents empirical evidence about the extent of this difference, in an exploratory attempt and in the case of the congressional elections coverage. To achieve this goal, we develop a theoretical stance that contends that Mexican press faces an incomplete, haphazard, and centralized democratic development, amidst a triumphant rhetoric of democratization from certain academic and political groups. This argumentation develops trough three stages: firstly, we present a review of the theory of the modernization of the Mexican press, as a result of its political transition. Secondly, we challenge that position by taking to the fore the many anachronistic practices that still remain in many Mexican newspapers and that were widespread in the authoritarian era. 
Finally, we elaborate on the concept of instrumentalization that, as a consequence of the latter, keeps the Mexican journalism captured between modernization and traditional practices.

In regard to our empirical enquiry, we did a content analysis using common variables to observe party bias; its main goal was to assess how the performance of a sample of national newspapers (published in Mexico City) compares to a sample of subnational newspapers, in terms of bias, and in the context of the congressional elections of 2015. Our findings show that this same event yields a less biased coverage in the national press than the strong bias found in the local outlets, particularly in favour of the party of the governor in office. The data confirm the presence of authoritarian local practices in the press and, thus, the impossibility to assert that the Mexican newspapers have arrived into a solid democratic phase.

\section{Media modernization versus the persistence of old practices}

The year 2000 is considered a hallmark in the contemporary Mexican history, because it was the moment when - for the very first time - a political party different from the hegemonic PRI won the presidential election. Nevertheless, this change did not happen overnight. On the contrary, it was the outcome of a process that started at least 20 years before, when National Action Party - and to a lesser degree Democratic Revolution Party - defeated PRI at municipal and state levels.

The transformation of the political system was supposed to parallel that of the media system. Thus, the new democratic phase required a new kind of press. That is, it was expected a transition from an authoritarian model of journalism to a more liberal practice. Amongst other things, it represented the detachment from the official discourse, avoid the exchange of favours for friendly coverage, and the practice of investigative journalism (Lawson, 2002; Wallis, 2004; Hughes, 2006). However, this was not the mere result of media's good will, since they were compelled to do it as well. 
According to the modernization hypothesis, the media transformation was the outcome of both exogenous and endogenous factors. ${ }^{1}$ The former are related - on the one hand - to an incipient political liberation fostered by a series of changes in the pressgovernment relationship (e.g. the privatisation of PIPSA, the state-owned company that controlled the newsprint). On the other, the arrival of new organisations such as TV Azteca and Reforma boosted the development of a more competitive media market and, hence, pushed the traditional news outlets to offer better content (Lawson, 2002). Regarding the endogenous factors, certain newsrooms adopted a more professional journalistic practice characterised by the notions of balance, objectivity, pluralism and public service; similar to the style promoted by outlets such as Proceso and La Jornada (Lawson, 2002; Hughes, 2006).

Notwithstanding, the hypothesis of the modernisation of Mexican journalism is problematic, because it takes for granted a homogeneous transformation of the media system as a whole. That is, using a limited sample of certain media organisations located in the most developed cities (mainly Mexico City, Guadalajara and Monterrey), it assumed that the situation for the rest of the country should be similar. However, reality proved otherwise, as it is consistently demonstrated by several studies on local and regional press (e.g. Orozco, 2010; De León, 2011; González, 2013; Reyna, 2014; Espino; 2016). The reason, as it will be discussed in the following sections, is that it is precisely at the regional level where the continuity of the practices that shaped the interaction between reporters and politicians during the PRI regime becomes evident.

Therefore, Mexican journalism is still determined by the same old practices that deters its proper modernization. Although local media represent the clearest example of this phenomenon, the so-called national press is not immune either. Those practices, which will be explained in the next paragraphs, are coercion towards reporters, partisan journalism, media agenda dominated by political elites, and lack of investigative reporting.

The main factor that hinders modernization is the constant coercion towards the press. To different extents and trough diverse means, journalistic practice in Mexico has been constrained by several actors; such as high-rank politicians, businessmen and, more recently, organised crime. Through the use of bribes for getting a friendly coverage,

\footnotetext{
${ }^{1}$ Under this logic, and keeping the proper distance, the Mexican case is consistent with other transformations of media systems in different countries, which were also produced by internal and external forces (Hallin \& Mancini, 2004b).
}

Global Media Journal México 14(27). Noviembre 2017 - abril 2018. Pp. 149-165. 
government advertising contracts, or even violence, journalists, editors and media owners are obliged to determine news content based upon external interests (Rodelo, 2009; De León, 2011; González, 2013; Relly \& González, 2014; Márquez, 2015; Holland \& Ríos, 2015; Del Palacio, 2015).

One of the most evident outcomes of coercion is bias, which is the systematic practice of favouring an actor or institution to the detriment of another in the news content. In other words, a biased news story is built upon incomplete information that deliberately reinforces - or not - certain actors or ideologies (McQuail, 1998; Fico, Feldman \& Love, 2006). As a matter of fact, and as a result of a clientelistic relationship, diverse empirical studies demonstrate the way local media tend to overtly support a specific political party, whether during electoral campaigns for governor (Andrade \& Trejo, 2011; Echeverría, 2013; Espino \& Mendoza, 2015), local or federal Congress (Aceves, 2010; Andrade, 2012), or presidential elections (Ortiz \& Gómez, 2013; Martínez, 2013).

The second factor is the ideological alignment of the Mexican media which, from the very beginning, has determined the journalistic practice. Historically, news outlets have defined their political stance, which shapes their editorial line and, thus, their agenda. In so doing, their content is a reflection of the ideologies they support. Under these circumstances, journalistic liberal values such as objectivity and political independence, are alien concepts for most of the Mexican reporters and publishers (Rodríguez, 1993; Pineda \& Del Palacio, 2003; Márquez, 2012; González, 2013). It is worth mentioning that partisan journalism is not necessarily an anti-democratic practice, because certain European media systems - such as the French, Danish or Norwegian have been overtly partisan (Hallin \& Mancini, 2004a). The problem with the Mexican case is that this practice is frequently the result of instrumentalization, instead of an honest political stance. That is, in not few cases, this alignment is the outcome of coercion, rather than the press own free will (González, 2013).

Another feature of the Mexican journalism is that political elites - whether local, regional or national - dominate media agenda. It means that news contents are built upon the official version, because government officials and political parties are the most frequent sources of information. Therefore, at least for journalists, political realm is not for citizens, who are usually absent from the news accounts; unless they are portrayed as victims of a catastrophe or beneficiaries of a public policy (Hallin, 1995; Orozco, 2010; 
De León, 2011, Márquez, 2012; Reyna, 2014; Martínez, González \& Miranda, 2015). This situation could also be understood as an endemic lack of interest on citizen issues shown by mainstream press in Mexico, which is another difference between the model of liberal journalism and the one practiced here (Hallin \& Mancini, 2004a).

As a result of the two previous factors, partisanship and lack of agenda control, proper journalistic investigation is constantly absent from mainstream media. By stressing the official version as the only version, or at least the more important, Mexican press fails in its duty to keep society informed. Furthermore, reporters are used to collect sound bites, instead of facts. Thus, as it will be discussed in the following sections, journalists tend to write standard news accounts instead of more elaborated stories, such as investigative reports; because the latter demand being proactive rather than reactive (Márquez, 2012; Reyna, 2014; Martínez, González \& Miranda, 2015; González, 2015).

In sum, whether voluntarily or involuntarily, very frequently Mexican media are subject to non-journalistic interests. This phenomenon is known as instrumentalization and it appears when, instead of responding to their audience, the news outlets are used by an external actor in order to publish or hide information (Hallin \& Mancini, 2004a). As a result, news content tends to favour or expose a member of the political elite, rather than keeping the citizens informed.

Although instrumentalization appears on a regular basis, it cannot be said that every single news outlet is subject to this situation at all times either. Such an argument would be similar to that of the overgeneralisation of the modernisation hypothesis. On the contrary, it is worth stressing that there are certain glimpses of a more independent investigative journalism (especially online) ${ }^{2}$ that allow to expect a possible future transformational wave, which might have a wider reach.

All of these aspects reinforce the idea that the modernisation process is neither automatic nor homogeneous, because it depends on both exogenous and endogenous factors (Hallin \& Mancini 2004a and 2004b). For the Mexican case, the former are represented by a more competitive media market, a clear decline of citizen partisanship, and the constant arrival of oppositional political parties to local and state governments. On the other hand, the endogenous factors are related to the particular features of each media system, such as the reporter-source relationship or the journalistic

\footnotetext{
${ }^{2}$ Since it is a relatively new phenomenon in Mexico, the implications of digital journalism for the overall Mexican media system have not been studied yet with the proper academic and methodologic rigour. Therefore, this theme represents a possible future research line.
}

Global Media Journal México 14(27). Noviembre 2017 - abril 2018. Pp. 149-165. 
professionalization. This means that the notion of change is connected with local processes, instead of global. Thus, rather than assuming a general development, it is more accurate to look at specific regions, and compare their own processes afterwards.

Based upon the local and general approaches, it can be argued that contemporary Mexican press is captive to its authoritarian past and its liberal ideals (Guerrero \& Márquez, 2014). In other words, current journalistic practice in Mexico oscillates between modernity and stagnation, between change and continuity (González, 2013). Being just in the middle of the process becomes evident by analysing the coverage of the 2015 legislative elections, which results will be presented and discussed in the following sections.

\section{Method}

The comparison we conducted is based on data from the project Congressional Election Analysis 2015 held by colleagues of the Mexican Network of Observatories, associated to the National Council for Education and Research of Communication Sciences (CONEICC) and took place between August 2015 and March 2016. That project implemented a content analysis of a sample of the lead newspapers in the states that the researchers belonged to, replicating a codebook that was used to measure the quality of information that news media produced about the elections (Martínez, 2013).

This source of data has some methodological implications for the sample for our analysis: the content units were only news stories - located in any section of the paper that cover the congressional elections, whether they were about candidates, national party leaders, opinions by third parties, etc. Hence, we exclude opinion stories, news about municipal, governor or local congress elections, and information about local issues (social movements, crime) that somehow relate to the election. A couple of sample methods were used, a composite week and a natural week (from April 27 to May 31) both obtained from the 60 days that the campaign lasts.

In regard to the geographical scope of the sample, the newspapers chosen were the most significant in their own states, from the point of view of its qualitative weight in public opinion and not their circulation. Therefore, the states and news outlets selected, respectively, were Monterrey, with "Milenio Norte" and "El Norte"; Guadalajara, with 
"NTR el Diario de Guadalajara" and "El Informador"; as well as Veracruz, with "Diario del Istmo", "Diario de Xalapa" y "La Opinión de Poza Rica". This states and news outlets are a very narrow sample of the dailies published in the nation, though they are representative, in a qualitative way, of the Mexican subnational press. As for the "national" newspaper in the sample (those published in Mexico City), by the same criteria we selected "Milenio" and "La Jornada", well known right and left journals, respectively. This center - periphery, capital and subnational comparison, it is based on these two types of newspapers. This leaves an uneven volume of units between both samples (87 national versus 251 subnational stories) and this fact, amongst other limitations of the research design, mean that the findings we present should be interpreted as exploratory rather than descriptive. Yet, some of the benefits of comparative research in the field of political communication are also present here: it renders visible - on the one hand - the attributes of a system that are taken for granted by the researcher, and - on the other phenomena that have not been conceptualized yet. In addition, it precludes ethnocentric generalizations (Hallin \& Mancini, 2004a).

From the original codebook of the project, we took the dimensions that assess party bias in the coverage of the campaign: visibility and treatment, and therefore, the variables of party and candidate covered, the valence of the input of the journalists (positive, negative and neutral), and whether there were comments exerted from political actors about candidates, and their valence. In addition, we measured the journalistic genres that framed the stories, the type of political actor portrayed, and the amount and type of sources referred in the news stories, as complementary indices for journalistic modernization. The next section presents the results from that analysis. 
Table 1. Treatment and visibility coding

\begin{tabular}{|c|c|c|c|c|c|c|c|c|c|c|c|c|c|c|c|c|c|c|c|c|c|c|c|c|c|c|}
\hline & & & \multicolumn{24}{|c|}{ PARTY WHOM THE CANDIDATE BELONGS } \\
\hline & & & \multicolumn{2}{|c|}{ PRI } & \multicolumn{2}{|c|}{ PAN } & \multicolumn{2}{|c|}{ PRD } & \multicolumn{2}{|c|}{$\begin{array}{c}\text { Nueva } \\
\text { Alianza } \\
\text { (PANAL) }\end{array}$} & \multicolumn{2}{|c|}{$\begin{array}{l}\text { Movimiento } \\
\text { Ciudadano }\end{array}$} & \multicolumn{2}{|c|}{$\begin{array}{c}\text { Partido } \\
\text { Verde } \\
\text { Ecologista } \\
\end{array}$} & \multicolumn{2}{|c|}{$\begin{array}{c}\text { Partido } \\
\text { Humanista }\end{array}$} & \multicolumn{2}{|c|}{$\begin{array}{l}\text { Partido del } \\
\text { Trabajo }\end{array}$} & \multicolumn{2}{|c|}{ Morena } & \multicolumn{2}{|c|}{$\begin{array}{c}\text { Partido } \\
\text { Encuentro } \\
\text { Social } \\
\end{array}$} & \multicolumn{2}{|c|}{$\begin{array}{l}\text { Independent } \\
\text { candidate }\end{array}$} & \multicolumn{2}{|c|}{$\begin{array}{l}\text { Local } \\
\text { party }\end{array}$} \\
\hline & & & N & $\%$ & N & $\%$ & N & $\%$ & $N$ & $\%$ & $N$ & $\%$ & N & $\%$ & $N$ & $\%$ & N & $\%$ & N & $\%$ & $N$ & $\%$ & N & $\%$ & $N$ & $\%$ \\
\hline \multirow{12}{*}{$\begin{array}{c}\text { Subnational } \\
\text { press }\end{array}$} & \multirow{4}{*}{ Type of actor } & Candidate & 110 & 90.2 & 36 & 85.7 & 39 & 97.5 & 19 & 100 & 38 & 95 & 2 & 20 & 24 & 100 & 32 & 97 & 34 & 94.4 & 30 & 96.8 & 8 & 100 & 0 & 0 \\
\hline & & Party representative & 8 & 6.6 & 6 & 14.3 & 0 & 0 & 0 & 0 & 0 & 0 & 8 & 80 & 0 & 0 & 0 & 0 & 1 & 2.8 & 0 & 0 & 0 & 0 & 0 & 0 \\
\hline & & Party member & 4 & 3.3 & 0 & 0 & 1 & 2.5 & 0 & 0 & 2 & 5 & 0 & 0 & 0 & 0 & 1 & 3 & 1 & 2.8 & 1 & 3.2 & 0 & 0 & 0 & 0 \\
\hline & & Senator or Deputies & 0 & 0 & 0 & 0 & 0 & 0.0 & 0 & 0 & 0 & 0 & 0 & 0 & 0 & 0 & 0 & 0 & 0 & 0 & 0 & 0 & 0 & 0 & 0 & 0 \\
\hline & \multirow{2}{*}{ Position } & Front page & 6 & 4.9 & 0 & 0 & 1 & 2.5 & 1 & 5.3 & 0 & 0 & 0 & 0 & 1 & 4.2 & 0 & 0 & 0 & 0 & 0 & 0 & 0 & 0 & 0 & 0 \\
\hline & & Inner pages & 116 & 95.1 & 42 & 100 & 39 & 97.5 & 18 & 94.7 & 40 & 100 & 10 & 100 & 23 & 95.8 & 33 & 100 & 36 & 100 & 32 & 100 & 8 & 100 & 0 & 0 \\
\hline & \multirow{3}{*}{$\begin{array}{c}\text { Comments from } \\
\text { journalists about } \\
\text { the actor }\end{array}$} & Neutral & 60 & 78.9 & 24 & 72.7 & 28 & 93.3 & 16 & 94.1 & 23 & 82.1 & 1 & 25 & 17 & 85 & 24 & 75 & 31 & 86.1 & 28 & 87.5 & 6 & 85.7 & 0 & 0 \\
\hline & & Favorable & 10 & 13.2 & 4 & 12.1 & 2 & 6.7 & 0 & 0 & 2 & 7.1 & 1 & 25 & 2 & 10 & 5 & 15.6 & 2 & 5.6 & 2 & 6.3 & 0 & 0.0 & 0 & 0 \\
\hline & & Negative & 6 & 7.9 & 5 & 15.2 & 0 & 0 & 1 & 5.9 & 3 & 10.7 & 2 & 50 & 1 & 5 & 3 & 9.4 & 3 & 8.3 & 2 & 6.3 & 1 & 14.3 & 0 & 0 \\
\hline & \multirow{3}{*}{$\begin{array}{c}\text { News story } \\
\text { treatment }\end{array}$} & Neutral & 1 & 16.7 & 2 & 40 & 0 & 0 & 0 & 0 & 0 & 0 & 0 & 0 & 0 & 0 & 0 & 0 & 0 & 0.0 & 0 & 0 & 0 & 0 & 0 & 0 \\
\hline & & Favorable & 0 & 0 & 0 & 0 & 0 & 0 & 0 & 0 & 0 & 0 & 0 & 0 & 0 & 0 & 0 & 0 & 0 & 0.0 & 0 & 0 & 1 & 100 & 0 & 0 \\
\hline & & Negative & 1 & 16.7 & 1 & 20 & 0 & 0 & 0 & 0 & 0 & 0 & 0 & 0 & 1 & 33.3 & 0 & 0 & 0 & 0.0 & 0 & 0 & 0 & 0 & 0 & 0 \\
\hline \multirow{12}{*}{$\begin{array}{c}\text { National } \\
\text { press }\end{array}$} & \multirow{4}{*}{ Type of actor } & Candidate & 7 & 35 & 1 & 25 & 6 & 60 & 0 & 0 & 4 & 80 & 1 & 16.7 & 0 & 0 & 1 & 100 & 0 & 0.0 & 1 & 100 & 0 & 0 & 0 & 0 \\
\hline & & Party representative & 5 & 25 & 2 & 50 & 2 & 20 & 1 & 100 & 1 & 20 & 2 & 33.3 & 0 & 0 & 0 & 0 & 9 & 90 & 0 & 0 & 0 & 0 & 0 & 0 \\
\hline & & Party member & 7 & 35 & 0 & 0 & 2 & 20 & 0 & 0 & 0 & 0 & 3 & 50 & 0 & 0 & 0 & 0 & 1 & 10 & 0 & 0 & 0 & 0 & 1 & 100 \\
\hline & & Senator or Deputies & 1 & 5 & 1 & 25 & 0 & 0 & 0 & 0 & 0 & 0 & 0 & 0 & 0 & 0 & 0 & 0 & 0 & 0 & 0 & 0 & 0 & 0 & 0 & 0 \\
\hline & \multirow{2}{*}{ Position } & Front page & 0 & 0 & 0 & 0 & 0 & 0 & 0 & 0 & 0 & 0 & 0 & 0 & 0 & 0 & 0 & 0 & 0 & 0 & 0 & 0 & 0 & 0 & 0 & 0 \\
\hline & & Inner pages & 20 & 100 & 4 & 100 & 10 & 100 & 1 & 100 & 5 & 100 & 6 & 100 & 0 & 0 & 1 & 100 & 10 & 100 & 1 & 100 & 0 & 0 & 1 & 100 \\
\hline & \multirow{3}{*}{$\begin{array}{c}\text { Comments from } \\
\text { journalists about } \\
\text { the actor }\end{array}$} & Neutral & 16 & 80 & 3 & 75 & 7 & 70 & 0 & 0 & 4 & 80 & 3 & 50 & 0 & 0 & 1 & 100 & 8 & 80 & 1 & 100 & 0 & 0 & 0 & 0 \\
\hline & & Favorable & 2 & 10 & 0 & 0 & 1 & 10 & 0 & 0 & 1 & 20 & 0 & 0 & 0 & 0 & 0 & 0 & 1 & 10 & 0 & 0 & 0 & 0 & 0 & 0 \\
\hline & & Negative & 0 & 0 & 0 & 0 & 2 & 20 & 1 & 100 & 0 & 0 & 2 & 33.3 & 0 & 0 & 0 & 0 & 1 & 10 & 0 & 0 & 0 & 0 & 0 & 0 \\
\hline & & Neutral & 1 & 5 & 0 & 0 & 2 & 20 & 1 & 100 & 1 & 20 & 0 & 0 & 0 & 0 & 0 & 0 & 0 & 0 & 0 & 0 & 0 & 0 & 0 & 0 \\
\hline & News story & Favorable & 0 & 0 & 0 & 0 & 1 & 10 & 0 & 0 & 0 & 0 & 0 & 0 & 0 & 0 & 0 & 0 & 0 & 0 & 0 & 0 & 0 & 0 & 0 & 0 \\
\hline & & Negative & 0 & 0 & 0 & 0 & 0 & 0 & 0 & 0 & 0 & 0 & 2 & 33.3 & 0 & 0 & 0 & 0 & 0 & 0 & 0 & 0 & 0 & 0 & 0 & 0 \\
\hline
\end{tabular}

Global Media Journal México 14(27). Noviembre 2017 - abril 2018. Pp. 149-165. 


\section{Findings}

This section presents our findings of party bias in our sample. It is worth mention that papers published in Mexico City are called national and the ones published in the states are called subnational. However, this labels are only related to the medium's scope, rather than its quality.

Regarding visibility, in sub national journals the frequency of stories granted to the Institutional Revolutionary Party (PRI) almost triples those about other strong parties, resulting in $28.2 \%$ for PRI, $11.1 \%$ for PAN (National Action Party, right), $10.6 \%$ for PRD (Democratic Revolutionary Party, left) and 10.4\% for Movimiento Ciudadano (left). On the opposite, in the national press, the stories for the PRI doubled (27.3\%) other parties' (19.5\% PRD, 13\% PAN, 10.4\% Verde Ecologista - Green Party - and 9.1\%, Movimiento Ciudadano).

Bias grows when we consider the visibility of the candidates, instead of parties. From the total of stories in subnational media, 29.6\% are about PRI candidates, $11.8 \%$ for PRD, 11.3\% for Movimiento Ciudadano, 11.4\% for PAN, 9.1\% for MORENA (left), 8.6\% for Partido del Trabajo (Labour Party, left), 8.1\% for Partido Encuentro Social (right), and 6.5\% for Partido Humanista (Christian, right).

Likewise, PRI had $4.9 \%$ of their stories in the front pages of subnational papers, followed by Nueva Alianza (left) and Partido Humanista (left), as well as $2.2 \%$ of stories for PRD. Neither PAN nor the rest of the parties had a single piece in the front page. On the contrary, no party deserved a front page in the national press.

About the treatment of parties and candidates, there is a less evident bias between the dailies. Both subnational and national papers rendered neutral accounts of political actors ( $80.6 \%$ and $73.2 \%$, respectively). Only $10.1 \%$ of the stories published on province papers were negative, $14.1 \%$ in national ones. The percentage of positive coverage was slightly higher in national outlets $(12.7 \%)$ than in sub nationals $(9.2 \%)$.

Considering these minimal frequencies, the three parties with more positive coverage in subnational press were Verde Ecologista (20\%), Partido del Trabajo (15.6\%) and PRI (13.2\%). Meanwhile, national papers gave positive coverage to Movimiento Ciudadano (14.3\%), PRI (11.1\%) and PRD (7.1\%). About negative coverage, higher frequencies were given to Partido Verde Ecologista (40\%), PAN (14.7\%) and 
independent candidates (14.3\%). Negative coverage from national papers was focused on Nueva Alianza (33.3\%), Verde Ecologista, and PRD (28.6\% both).

Both subnational and national journalists expressed few comments about parties or candidates in their stories ( $0.6 \%$ y $14.5 \%$, respectively) and almost half of those were non neutral (55\% y 66\%, respectively). Notwithstanding, comments from other sources are found in the stories, particularly in national press $(31 \%$ of the stories had one, compared to the $4 \%$ in the sub national press). Furthermore, those comments are biased: $30 \%$ of those found in sub national press are negative against PRI, 22\% against Movimiento Ciudadano, and $16.7 \%$ towards PAN and PRD. In the national press, however, $45.8 \%$ of the comments are negative for the PRI, 37.5\% towards PRD and $20.8 \%$ towards PAN.

Our data contains other three significant traits in regard to the modernisation hypothesis. Firstly, news stories are the most utilised journalistic genre in both types of dailies. In the local press, only $1.7 \%$ of the pieces are investigative reports and $0.2 \%$ interviews; whilst in the national press $5.7 \%$ of the stories are based on interviews and $4.6 \%$ are investigative reports. Secondly, political actors overwhelmingly dominate the agenda: $95.6 \%$ of the stories were about them, mainly candidates (72\%) and party representatives $(4.8 \%)$, compared to other members of society such as union leaders $(1.3 \%)$, common citizen $(1.0 \%)$, entrepreneurs or investors $(0.8 \%)$, experts $(0.6 \%)$, supra national organizations $(0.4 \%)$ and religious leaders $(0.2 \%)$. On the other hand, in the national press, only $6.4 \%$ of the stories portrait nonpolitical actors such as common citizens (3.4\%), religious leaders $(2.3 \%)$ and experts (1.1\%). Finally, the range of sources included in the news stories is limited: local press involves one single source in the $72.3 \%$ of the news stories, and $85.7 \%$ of them are political actors. In that sense, $32.2 \%$ of the news stories of the national press rely on a single source, and $90.3 \%$ of them are political actors.

\section{Discussion and conclusions}

The aim of this section is to present the general discussion of the findings and their implications for the overall argument of the so-called Mexican media modernisation. In so doing, the content will emphasise coincidences and divergences of the results, which 
reinforce the hypothesis that, instead of a general modernisation, both national and local press in Mexico present different degrees of this phenomenon. That is, both types of media organisations share simultaneously modern features, but also less modern aspects.

Regarding political bias, one shared aspect by both kind of news outlets is the PRI visibility, because nearly one third of the coverage was focussed on this party in all of the analysed newspapers. However, local papers tended to stress this situation because PRI got nearly three times more coverage (28\%) than its closer competitors: PAN (11\%), PRD $(10.6 \%)$ and $\mathrm{MC}(10.4 \%)$. Even though the distance between the first and the rest of the competitors was shorter, this trend was also kept at the national level: PRI (27.3\%), PRD (19.5\%), PAN (13\%) and PVEM (9.1\%).

As individual actors but not as institutions, the candidates' visibility presents a similar pattern. Whilst at local level PRI obtained $29.6 \%$ of the coverage and its closer competitor (PAN) 11\%, at the national level the distance was shorter once again: PRI (38.1\%) and PRD (28.6\%). Furthermore, news stories regarding the elections were scarcely published on front page. Nonetheless, PRI got $5 \%$ of those stories at local level, but none of the parties reached front page at national level.

Regarding the treatment of the information, there is also a similar pattern in both types of media organisations. National and local newspapers offered a neutral treatment of the information. That is, the use of favourable or unfavourable adjectives for the descriptions was rather limited. For that reason, PRI obtain overtly positive coverage in only $13 \%$ of the stories at the local level and $11 \%$ at national level.

On the other hand, a significant difference between both sets of media is the degree of professionalization, roughly defined here as the use of diverse sources of information (citizens amongst them) and, thus, the practice of investigative journalism. According to the findings, the Mexican national press tends to be more professional that its local counterpart. This is because $10 \%$ of its news stories were investigative reports, in comparison to the $2 \%$ of the local publications. Nonetheless, in both cases the practice of this kind of journalism is rather limited. This is consistent with the use of more than one source of information in the news stories which, once again, was more frequent in the newspapers published in Mexico City than those published in the states: $68 \%$ and $27 \%$, respectively.

In sum, assuming a general modernisation or stagnation of the Mexican press is problematic, because the empirical evidence proved otherwise. That is, both local and 
national media simultaneously presented features that could be considered modern, but also some others less modern. Regarding the latter, all the newspapers presented a clearly deferential coverage of PRI, such as it was common during the 70 years that this political party ruled the country. This was evident considering the visibility of both the party and its candidates during the period of study, in which the ratio of stories about the competitors are nearly three to one in favour of PRI. Likewise, there were more front page news stories about this party than for the rest. Furthermore, as a way of comparison, PRI got less negative comments than PAN, PRD or MC. On the other hand, both sets of news organisations coincided in a neutral treatment of the information about the campaigns, because overt support towards parties and candidates was less frequent; although, once again, PRI tended to be favoured by the comments.

Since these findings are significantly more evident at the local level, it can be argued that the journalistic practice outside Mexico City tends to be passive and even instrumentalized by local governments ${ }^{3}$ through different means of coercion. Notwithstanding, national press is not immune to these practices either, even though it tends to be more professional. That is, in spite of giving more visibility to PRI, just as their state counterparts, and although still limited, national newspapers published more investigative reports and, hence, presented different versions of the events they covered.

In short, this article argues that instead of a general modernisation or stagnation of the Mexican press, the empirical evidence points at the continuation of certain authoritarian practices in both national and local press, but this phenomenon is significantly more evident for the latter. However, there are also certain signs of a more professional practice in both sets of media, although it tends to be more frequent at the national level.

\section{References}

Andrade, P., \& Trejo, A. (2011). Análisis de la prensa como referente del comportamiento electoral. El caso Veracruz. Observatorio (OBS), 5, 267-284.

Andrade, P. (2012). Las elecciones 2010 en Veracruz y el comportamiento de la prensa. Razón y Palabra, 17(79).

\footnotetext{
${ }^{3}$ All of the state governments included in this study come from the PRI.

Global Media Journal México 14(27). Noviembre 2017 - abril 2018. Pp. 149-165.
} 
Aceves, F. (2010). La democracia no pasa por las pantallas: desigualdad, desequilibrio y ausencia de pluralismo en la cobertura informativa de las elecciones de 2009 en Jalisco. Quorum Académico, 7(2), 57-74.

De León, S. (2011). Comunicación pública, transición política y periodismo en México: el caso de Aguascalientes. Comunicación y Sociedad, 15, 43-69

Del Palacio, C. (2015). Periodismo impreso, poderes y violencia en Veracruz 2010-2014. Estrategias de control de la información. Comunicación y Sociedad, 24, 19-46

Echeverría, M. (2013). Los partidos y sus medios: cobertura y sesgo en las elecciones del 2012 en Yucatán. In E. Poot (Ed.), Los procesos Electorales Yucatecos de 2012. Mérida: UADY.

Espino, G. (2016). Periodistas precarios en el interior de la República mexicana: atrapados entre las fuerzas del mercado y las presiones de los gobiernos estatales. Revista Mexicana de Ciencias Políticas y Sociales, 228, 1-30

Espino, G., \& Mendoza, E. (2015). Los gobernadores, enclaves del autoritarismo en México. Sometimiento y subordinación de los medios de comunicación locales. México: Fontamara.

Fico, F., Freedman, E., \& Love, B. (2006). Partisan and Structural Balance in Newspaper Coverage of US Senate Races in 2004 with Female Nominees. Journalism and Mass Communication Quarterly, 83(1), 43-57.

González, R. A. (2013). New players, same old game. Change and continuity in Mexican journalism. Germany: Lambert Academic Publishing

González, R. A. (2015). Investigative journalism in Mexico: Between ideals and realities. The case of Morelia. Journal of Latin American Communication Research, 5(1), 3-36

Guerrero, M. A. \& Márquez, M. (2014). Media systems and communication policies in Latin America. UK: Palgrave Macmillan

Hallin, D. C. (1995). Dos instituciones un camino: Television and the State in the 1994 Mexican election. Paper presented at the XIX Annual Congress of the Latin American Studies Association, Washington DC, September

Hallin, D. C., \& Mancini, P. (2004a). Comparing Media Systems. Three Models of Media and Politics. Cambridge: Cambridge University Press.

Hallin, D. C. \& Mancini, P. (2004b). Americanization, globalization and secularization. Understanding the Convergence of Media Systems and Political Communication. 
In Esser, F. \& Pfetsch, B. (Eds.). Comparing political communication. Theories, cases and challenges (pp. 25-44). USA: Cambridge University Press

Holland, B. E. \& Ríos, V. (2015). Informally governing information: how criminal rivalry leads to violence against press in Mexico. Journal of Conflict Resolution, 1-25

Hughes, S. (2006). Newsrooms in conflict. Journalism and the democratization of Mexico. USA: University of Pittsburgh Press

Lawson, C. H. (2002). Building the fourth estate. Democratization and the rise of a free press in Mexico. USA: University of California Press

Márquez, M. (2012). Valores normativos y prácticas del reporteo en tensión: percepciones profesionales de periodistas en México. Cuadernos de Información, $30,97-110$

Márquez, M. (2014). Professionalism and journalism ethics in post-authoritarian Mexico: perceptions of news for cash, gifts, and perks. In Wyatt, W. (Ed.). The ethics of journalism: individual, institutional and cultural influences (pp. 55-63). UK: I.B. Tauris; Reuters Institute for the Study of Journalism, University of Oxford

Márquez, M. (2015). El impacto de la violencia criminal en la cultura periodística posautoritaria: La vulnerabilidad del periodismo regional en México. In Del Palacio, C. (coord.). Violencia y periodismo regional en México (pp. 15-47). México: Juan Pablos Editor

Martínez, F. (2013). La contienda electoral federal 2012 en la prensa mexicana. Revista Mexicana de Opinión Pública, (15), 61-79.

Martínez, F. J., González, R. A. \& Miranda, O. M. (2015). Actores políticos y sociales de los telediarios: Una tarea pendiente de las televisoras mexicanas. Revista Latina de Comunicación Social, 70, 750-764

McQuail, D. (1998). La acción de los medios. Buenos Aires: Amorrortu

Ortiz, M., \& Gómez, R. (2013). Una mirada a las elecciones de 2012 desde la frontera norte de México. El caso de la prensa de Baja California. Versión, Estudios de Comunicación y Política, (32), 51-71.

Orozco, R. (2010). Relaciones prensa-gobierno en Tepic. Una caracterización de prácticas dominantes en el periodismo local de México. México: Universidad de Guadalajara

Pineda, A. \& Del Palacio, C. (Coords.) (2003). Prensa decimonónica en México. México: Universidad de Guadalajara/UMSNH/CONACYT 
Relly, J. E. \& González, C. (2014). Silencing Mexico: A study of influences on journalists in the Northern states. The International Journal of Press/Politics, 19(1), 108-131

Reyna, V. H. (2014). Nuevos riesgos, viejos encuadres: la escenificación de la inseguridad pública en Sonora. México: El Colegio de Sonora

Rodelo, F. (2009). Periodismo en entornos violentos: El caso de los periodistas de Culiacán, Sinaloa. Comunicación y Sociedad, 12, 101-118.

Rodríguez, R. (1993). Prensa vendida. México: Grijalbo

Wallis, D. (2004). The media and democratic change in Mexico. Parliamentary Affairs, $57(1), 118-130$ 